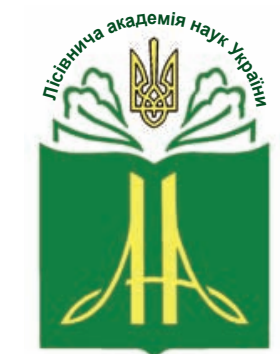

Forestry Academy of Sciences of Ukraine
Наукові праці Лісівничої академії наук України Proceedings of the Forestry Academy of Sciences of Ukraine http://fasu.nltu.edu.ua https://doi.org/10.15421/412107

Article received 2021.02.06

Article accepted 2021.06.10
ISSN 1991-606X print

ISSN 2616-5015 online

(a) $\triangle$ Correspondence author

Natalia Bratilova

nbratilova@yandex.ru
Krasnoyarskii rabochii prospect, 31, Krasnoyarsk, 660037, Russian Federation

\title{
Формирование кроны кедра сибирского за 12-летний период после декапитации (пригородная зона г. Красноярска)
}

\author{
Д. А. Гришлов ${ }^{1}$, Н.П. Братилова² Р. Н. Матвеева ${ }^{3}$, О. Ф. Буторова ${ }^{4}$
}

Показаны особенности формирования кроны кедра сибирского (Pinus sibirica Du Tour) после декапитацุии, произрастающего на плантации «Метеостанция» в Учебно-опытном лесхозе Караульного лесничества в условиях юга Средней Сибири. Объектом исследований являлась 54-летняя плантация кедра сибирского, выращенная из семян, заготовленных в 1964 г. в Лениногорском лесхозе (Республика Казахстан). Декапитация проведена у деревьев 42-летнего возраста в 2005 г. с оставлением ствола высотой 1,4-1,7 м. Верхняя часть кроны удалена на 50,0-66,7\%. В 2017 г. деревья достигли высоты 5,6-9,1 м. Количество лидирующих побегов, заменивиих ияентральный, составило 3-7 ит., длина которых за 12-летний период достигла 4,0-7,6 м. Деревья с диаметром ствола 12-18 см имели по 3-4, с диаметром 20-26 см- по 6-7 шт. лидируюших побега.

Установлено, что уровень изменчивости высоты деревьев низкий; прироста побегов, диаметра ствола средний, количества лидирующих побегов - высокий. Наибольшей высотой $(9,1$ м) отличалось дерево № 4-98, превосходя другие особи на 8,3-62,5\%. Сопоставлено количество боковых ветвей, образовавиихся на лидирующих побегах за 5 лет (2013-2017 г2.). Отмечено, что их средний прирост за исследуемый период находился в пределах 23,6-45,5 см. Между диаметром ствола и числом лидирующих побегов коэффициент корреляции (r) равен 0,619; числом лидирующих побегов и количеством сформированных боковых ветвей спустя 7-12 лет после декапитации - 0,770, диаметром ствола при обрезке и высотой деревьев после 12 лет декапитацчии $-0,738$.

Ключевые слова: Pinus sibirica; прирост; плантация; лидирующчий побег; обрезка кроны; лениногорское происхождение; Красноярский край.

\footnotetext{
Гриилов Дмитрий Андреевич - аспирант кафедры селекции и озеленения. Сибирский Государственный университет науки и технологий имени академика М.Ф. Решетнева, пр. Мира, 82, г. Красноярск, 660049, Россия. Тел.: (391)222-73-95. E-mail: grishlova@ mail.ru ORCID: https://orcid.org/0000-0003-3734-2541

2 Братилова Наталья Петровна - доктор сельскохозяйственных наук, зав. кафедрой селекции и озеленения. Сибирский Государственный университет науки и технологий имени академика М.Ф. Решетнева, пр. Мира, 82, г. Красноярск, 660049, Россия. Тел.: (391)222-73-95. E-mail: nbratilova@yandex.ru ORCID: https://orcid.org/0000-0002-2918-9690

3 Матвеева Римма Никитична - доктор сельскохозяйственных наук, профессор кафедры селекции и озеленения. Сибирский Государственный университет науки и технологий имени академика М.Ф. Решетнева, пр. Мира, 82, г. Красноярск, 660049, Россия. Тел.: (391)222-73-95. E-mail: matveevaRN@yandex.ru ORCID: https://orcid.org/0000-0002-3476-9622

4 Буторова Ольга Федоровна - доктор сельскохозяйственных наук, профессор кафедры селекции и озеленения. Сибирский государственный университет науки и технологий имени академика М.Ф. Решетнева, пр. Мира, 82, г. Красноярск, 660049, Россия. Тел.: (391)222-73-95. E-mail: Butorova.olga@mail.ru ORCID: https://orcid.org/0000-0001-8575-7464
} 
Введение. О целесообразности проведения декапитации деревьев с целью уменьшения их высоты и формирования низкоопущенной кроны для улучшения условий проведения селекционных исследований, нарезки черенков, сбора шишек с низкорослых деревьев посвящены работы многих исследователей. По сосне обыкновенной в данном направлении следует отметить работы В.М. Белобородова (1979), В.И. Долголикова (1981), В.В. Тараканова, В.П. Демиденко, Я.Н. Ишутина, Н. Т. Бушкова (2001), P. S. Mederski, M. Bembenek, \& D. Nadolna (2013). В.И. Долголиков (1981) разработал практические рекомендации по декапитации деревьев Pinus sylvestris L. при создании низкорослых семенных плантаций.

М.М. Вересин, Ю.П. Ефимов, Ю.Ф. Арефьев (1985) предлагали два способа декапитации сосны обыкновенной: регулярный (ежегодный или через год) и периодический (через определённое количество лет, срезая несколько приростов побега сразу).

Ряд исследователей (Извекова, 1972; Попов, 1982; Mäkinen, Verkasalo, \& Tuimala, 2014; MorenoFernández et al., 2014) изучали влияние обрезки кроны на рост сосны и ели, а также на рост лиственницы Сукачева (Родин, Тимофеев, 1989). Значительное внимание уделено изучению влияния декапитации на формирование кроны и семеношение кедровых сосен (Вересин, Ефимов, Арефьев, 1985; Бех, 1989; Щерба, Водин, 2000; Водин, Шкикунов, Селюк, 2002; Bae et al., 2008; Jae-Seon, Chul-Woo, Hyun-Seok, \& Chan-Hoon, 2009; Никитенко, 2010; Братилова, Шамова, 2014; Братилова, 2015; Матвеева, Буторова, Нарзяев, Гришлов, Иванов, 2018). Исследователями предложены разные способы декапитации крон с интенсивностью 55-75\%, отмечено стимулирующее влияние обрезки на разрастание крон, на увеличение семеношения вследствие формирования многовершинности.

Однако многие вопросы обезвершинивания хвойных деревьев, в том числе и Pinus sibirica $\mathrm{Du}$ Tour, которые касаются возраста деревьев при декапитации, высоты обрезки, формирования лиди- рующих побегов остаются малолизученными, что и определяет актуальность данного исследования.

Объекты и методы исследований. Объектом исследований являлась плантация Pinus sibirica лениногорского происхождения, произрастающая на участке «Метеостанция». Предмет исследований - деревья Pinus sibirica, декапитированные в 42-летнем возрасте. Целью исследований явилось установление особенностей формирования кроны деревьев кедра сибирского лениногорского происхождения (Казахстан) за 12-летний период после декапитации в зависимости от показателей диаметра ствола декапитируемых деревьев и количества лидирующих побегов.

Декапитированные деревья на плантации представлены потомством лучших особей искусственного насаждения кедра сибирского (местоположение: $50^{0} 12^{`}$ с.ш., $85^{0} 33^{`}$ в.д., 1700 м над уровнем моря).

Исследуемая плантация расположена на территории Караульного лесничества Учебно-опытного лесхоза СибГУ, где климатические условия благоприятны для произрастания кедра сибирского. Почва на участке серая лесная, легко суглинистая, слабо оподзоленная. Схема посадки деревьев $-5 \times 5$ м.

Декапитация проведена в 2005 г., когда возраст деревьев составил 42 года. В 2017 г. измерены высота, диаметр ствола, приросты в высоту боковых побегов, заменивших центральный, а также другие показатели декапитированных деревьев. Методика проведения исследования общепринятая для лесоводства и лесной таксации. Уровень изменчивости оценивали по шкале С. А. Мамаева (1973). Результаты исследований обработаны статистически с помощью пакета программ Microsoft Office.

Результаты и их обсуждение. Высота деревьев до декапитации в 42-летнем возрасте (2005 г.) варьировала от 3,3 до 4,5 м, диаметр ствола - от 9,5 до 23,6 см. Средний диаметр кроны составил 3,8$4,3 \mathrm{~m}$.

После обрезки в 2005 г. высота стволов составила 1,4-1,7 м. Удаление верхней части кроны проведено на 50,0-66,7\% (табл. 1).

Таблица 1

Таксационные показатели деревьев при декапитации в 2005 году

\begin{tabular}{|c|c|c|c|c|c|c|c|}
\hline \multirow{2}{*}{$\begin{array}{l}\text { Номер } \\
\text { дерева }\end{array}$} & \multicolumn{2}{|c|}{ Высота, м } & \multicolumn{2}{|c|}{$\begin{array}{c}\text { Спиленная часть, } \\
\text { м }\end{array}$} & \multirow{2}{*}{$\begin{array}{c}\text { Количество } \\
\text { оставленных } \\
\text { лидирующих } \\
\text { побегов, шт. }\end{array}$} & \multicolumn{2}{|c|}{$\begin{array}{c}\text { Диаметр ствола } \\
\text { возле поверхности почвы }\end{array}$} \\
\hline & $\begin{array}{l}\text { дерева до } \\
\text { декапитации }\end{array}$ & $\begin{array}{l}\text { ствола после } \\
\text { декапитации }\end{array}$ & M & $\% \kappa X_{\text {cp. }}$ & & cM & $\%$ к $X_{\text {cp. }}$ \\
\hline 1 & 2 & 3 & 4 & 5 & 6 & 7 & 8 \\
\hline $4-19$ & 3,3 & 1,4 & 1,9 & 57,6 & 5 & 14,4 & 82,3 \\
\hline $4-33$ & 4,5 & 1,7 & 2,8 & 62,2 & 6 & 19,5 & 111,4 \\
\hline $4-46$ & 4,2 & 1,5 & 2,7 & 64,3 & 6 & 22,5 & 128,6 \\
\hline $4-60$ & 3,2 & 1,6 & 1,6 & 50,0 & 3 & 9,5 & 54,3 \\
\hline $4-73$ & 4,3 & 1,6 & 2,7 & 62,8 & 7 & 20,4 & 116,6 \\
\hline $4-85$ & 3,3 & 1,5 & 1,8 & 54,5 & 4 & 16,4 & 93,7 \\
\hline
\end{tabular}


Продолж. табл. 1

\begin{tabular}{cccccccc}
\hline 1 & 2 & 3 & 4 & 5 & 6 & 7 & 8 \\
\hline $4-98$ & 4,4 & 1,5 & 2,9 & 65,9 & 4 & 19,7 & 112,6 \\
$4-117$ & 4,5 & 1,6 & 2,9 & 64,4 & 4 & 20,4 & 116,6 \\
$4-153$ & 3,9 & 1,4 & 2,5 & 64,1 & 7 & 13,6 & 77,7 \\
$4-163$ & 3,9 & 1,3 & 2,6 & 66,7 & 7 & 18,6 & 106,3 \\
Среднее & 4,0 & 1,5 & 2,5 & 61,2 & 5,3 & 17,5 & 100,0 \\
значение & & & & & & & \\
\hline
\end{tabular}

К 2017 г. боковые побеги из оставленных мутовок в количестве 3-7 шт. заменили центральный.
Высота декапитированных деревьев варьировала от 5,6 (дерево № 4-60) до 9,1 м (№ 4-98) (табл. 2).

Таксационные показатели декапитированных деревьев в 2017 году

\begin{tabular}{ccccccc}
\hline \multirow{2}{*}{$\begin{array}{c}\text { Номер } \\
\text { дерева }\end{array}$} & \multicolumn{2}{c}{ Высота } & \multicolumn{2}{c}{ Длина лидирующих } \\
побегов & \multicolumn{2}{c}{ Диаметр ствола } \\
\cline { 2 - 7 } & м & \% к X ср. & за 12 лет, м & $\%$ к Х ср. & см & \% к X ср. \\
\hline $4-19$ & 6,5 & 89,0 & 5,1 & 86,2 & 16 & 76,2 \\
$4-33$ & 7,5 & 102,7 & 5,8 & 100,0 & 24 & 114,3 \\
$4-46$ & 8,4 & 115,1 & 6,9 & 119,0 & 24 & 114,3 \\
$4-60$ & 5,6 & 76,7 & 4,0 & 69,0 & 12 & 57,1 \\
$4-73$ & 7,9 & 108,2 & 6,4 & 110,3 & 24 & 114,3 \\
$4-85$ & 7,0 & 95,9 & 5,5 & 94,8 & 18 & 85,7 \\
$4-98$ & 9,1 & 124,6 & 7,6 & 131,0 & 22 & 104,8 \\
$4-117$ & 7,2 & 98,6 & 5,6 & 96,6 & 24 & 114,3 \\
$4-153$ & 7,6 & 104,1 & 6,2 & 106,9 & 26 & 123,8 \\
$4-163$ & 6,6 & 90,4 & 5,3 & 91,4 & 20 & 95,2 \\
Среднее & 7,3 & 100,0 & 5,8 & 100,0 & 21,0 & 100,0 \\
значение & & & & & & \\
\hline
\end{tabular}

Различие деревьев по высоте составило до 1,6 раза. Большей высотой отличалось дерево № 4-98.

Длина боковых ветвей, заменивших центральный побег, за 12-летний период составила 4,07,6 м. Максимальная длина ветвей отмечена также у дерева 4-98 - на 7,0-90,0\% больше в сравнении с другими особями. Общий вид деревьев, спустя 12 лет после декапитации, представлен на рис. 1.

Диаметр ствола деревьев возле поверхности почвы в 2017 г. составил от 12 до 26 см. Наибольшим диаметром ствола характеризовались деревья № 4-33, 4-46, 4-73, 4-117. Деревья с меньшим диаметром ствола (12-18 см) имели по 3-4 лидирующих побега, заменивших центральный; деревья диаметром 20-26 см - по 6-7 шт. Установлена значительной тесноты связь $(\mathrm{r}=0,619)$ между диаметром ствола (х) и количеством лидирующих побегов (у). Уравнение связи имеет вид: $\mathrm{y}=-0,0043 \mathrm{x}^{2}+$ $+0,375 \mathrm{x}-0,573\left(\mathrm{R}^{2}=0,385\right)$.
Межу диаметром ствола при обрезке (х) и высотой деревьев через 12 лет после декапитации (у) установлена высокой тесноты связь $(\mathrm{r}=0,738)$. Уравнение связи имеет вид: $\mathrm{y}=-0,013 \mathrm{x}^{2}+0,665 \mathrm{x}-$ $0,658\left(\mathrm{R}^{2}=0,594\right)$.

Отмечен низкий уровень варьирования высоты деревьев, средний - величины прироста побегов, диаметра ствола, высокий - количества лидирующих побегов (табл. 3).

Средний прирост по высоте лидирующего побега исследуемых деревьев за 5-летний период (20132017 гг.) находился в пределах 23,6-45,5 см (табл. 4).

Наибольшее значение прироста (45,5 см) зафиксировано у дерева № 4-73, что на 12,1-71,0\% выше в сравнении с другими. Наименьшим приростом отличались деревья 4-117 и 4-33, значение которого составило 23,6-29,9 см (рис. 2).

Сопоставлено среднее количество боковых ветвей, образовавшихся за 5-летний период в мутовках лидирующих побегов (табл. 5). 

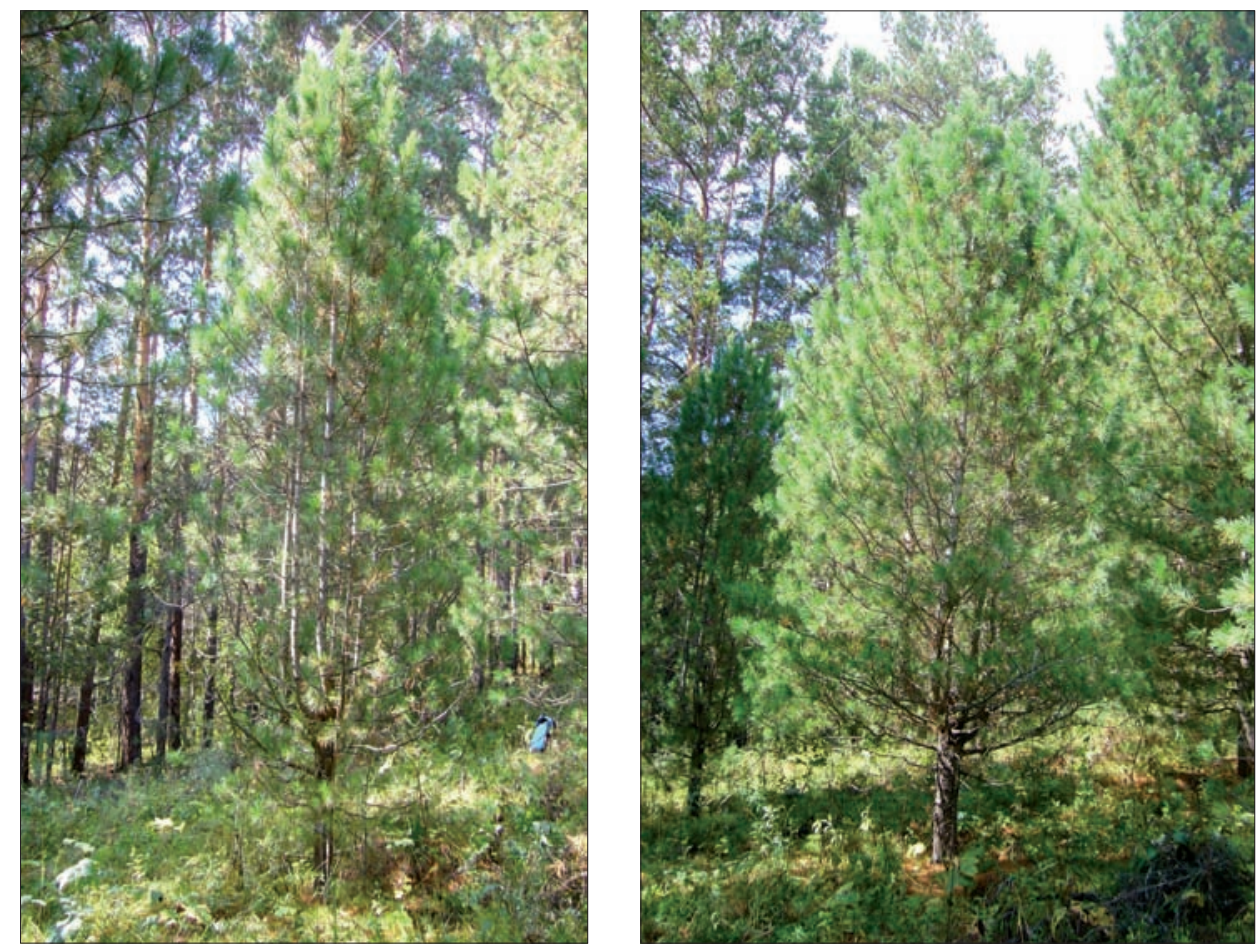

Рис. 1. Восстановление кроны у декапитированных деревьев 4-19 и 4-33 в 2017 году

Таблича 3

Показатели декапитированных деревьев

\begin{tabular}{lccccc}
\hline \multicolumn{1}{c}{ Показатель } & $\mathrm{X}_{\text {cp. }}$ & $\pm \mathrm{m}$ & $\mathrm{V}, \%$ & $\mathrm{P}, \%$ & Уровень изменчивости \\
\hline Высота в 2017 г., м & 7,3 & 0,32 & 13,7 & 4,3 & низкий \\
Прирост за 12 лет, м & 5,8 & 0,32 & 17,2 & 5,4 & средний \\
Диаметр ствола, см & 21,0 & 1,41 & 21,2 & 6,7 & высокий \\
$\begin{array}{l}\text { Количество лидирующих } \\
\text { побегов, шт. }\end{array}$ & 5,3 & 0,47 & 28,2 & 8,9 & высокий \\
\hline
\end{tabular}

Таблица 4

Прирост лидирующего побега у декапитированных деревьев

\begin{tabular}{ccccccc}
\hline \multirow{2}{*}{$\begin{array}{c}\text { Номер } \\
\text { дерева }\end{array}$} & \multicolumn{5}{c}{ Прирост по годам, см } & $\begin{array}{c}\text { Средний } \\
\text { за 5-лет }\end{array}$ \\
\cline { 2 - 6 } $4-19$ & 2013 & 2014 & 2015 & 2016 & 2017 & 35,0 \\
$4-33$ & 40,6 & 27,9 & 21,5 & 48,6 & 36,2 & 29,9 \\
$4-46$ & 19,3 & 26,4 & 32,7 & 38,5 & 32,9 & 40,6 \\
$4-60$ & 31,1 & 41,7 & 38,2 & 43,1 & 48,9 & 26,6 \\
$4-73$ & 20,0 & 35,8 & 33,6 & 24,1 & 19,7 & 45,5 \\
$4-85$ & 39,6 & 46,2 & 50,2 & 46,2 & 45,1 & 39,4 \\
$4-98$ & 19,8 & 39,5 & 44,8 & 48,0 & 44,9 & 31,2 \\
$4-117$ & 32,5 & 30,3 & 43,1 & 34,5 & 15,4 & 23,6 \\
$4-153$ & 14,1 & 31,2 & 16,1 & 27,5 & 29,3 & 40,6 \\
$4-163$ & 30,0 & 36,0 & 48,0 & 42,0 & 47,0 & 38,5 \\
Среднее & 43,8 & 13,2 & 32,6 & 42,2 & 60,8 & 35,1 \\
значение & 29,1 & 32,8 & 36,1 & 39,5 & 38,0 & \\
\hline
\end{tabular}




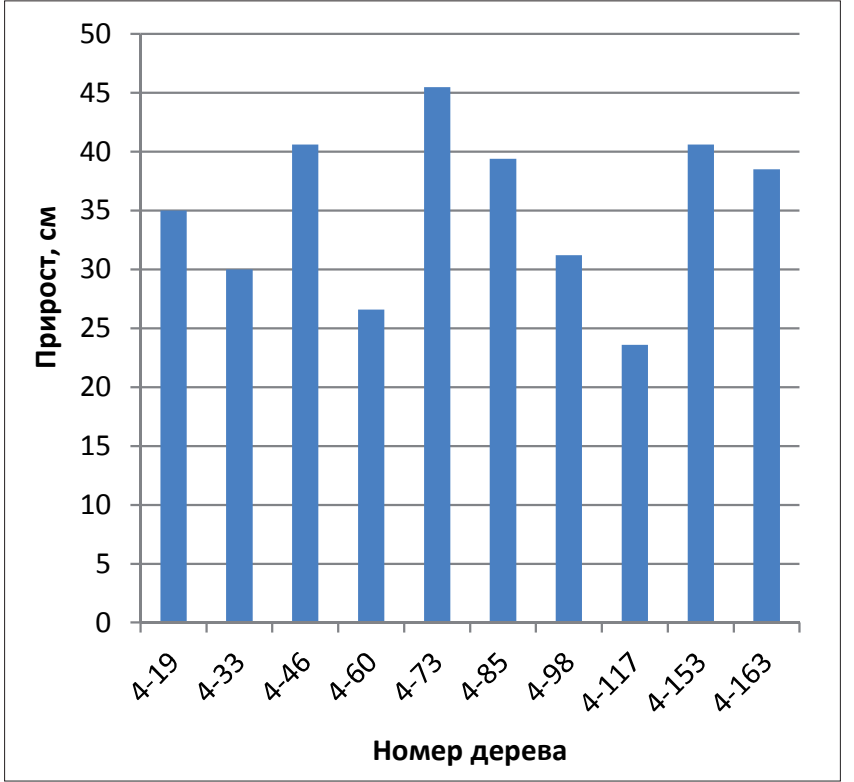

Рис. 2. Средний прирост за 5 лет лидирующих побегов декапитированных деревьев
В мутовках отдельных деревьев в среднем образовалось по 4,4-7,9 боковых ветвей. Слабое формирование ветвей в мутовках наблюдалось у дерева 4-117. Интенсивное разрастание кроны (по 7,2-7,9 шт. в мутовках) отмечено у деревьев 4-46, 4-73, 4-163, что на 10\% и более превышает среднее значение.

Суммарное количество боковых ветвей на побегах за 5-летний период варьировало от 85 (дерево № 4-60) до 253 шт. (№ 4-73). При этом минимальное значение (13,0 шт.) зафиксировано у дерева 4-60 в 2013 г., максимальное - в том же году у дерева 4-163 (рис. 3).

Между количеством оставленных при декапитации лидирующих побегов (х) и суммарным количеством образовавшихся боковых ветвей на побегах за 5-летний период (у) наблюдается тесная прямая связь $(\mathrm{r}=0,77)$ (рис. 4$)$.

Установлено увеличение количества боковых ветвей на побегах после декапитации при лидирующих 6-7 штук.

Таблииа 5

Среднее количество боковых ветвей в мутовках за 5-летний период, шт.

\begin{tabular}{cccccccc}
\hline $\begin{array}{c}\text { Номер } \\
\text { дерева }\end{array}$ & 2013 г. & 2014 г. & 2015 г. & 2016 г. & 2017 г. & Всего & $\begin{array}{c}\text { Среднее } \\
\text { значение }\end{array}$ \\
\hline $4-19$ & 5,6 & 5,0 & 4,4 & 5,0 & 4,2 & 24,2 & 4,8 \\
$4-33$ & 8,8 & 5,5 & 6,0 & 4,8 & 4,8 & 30,0 & 6,0 \\
$4-46$ & 8,0 & 5,3 & 8,7 & 7,2 & 7,3 & 36,5 & 7,3 \\
$4-60$ & 4,3 & 6,7 & 5,7 & 6,0 & 5,7 & 28,3 & 5,7 \\
$4-73$ & 8,4 & 5,6 & 7,9 & 7,0 & 7,3 & 36,1 & 7,2 \\
$4-85$ & 5,2 & 7,2 & 7,8 & 6,5 & 7,5 & 34,2 & 6,8 \\
$4-98$ & 7,0 & 4,8 & 7,2 & 5,0 & 8,0 & 32,0 & 6,4 \\
$4-117$ & 6,8 & 4,0 & 3,5 & 3,8 & 4,2 & 22,2 & 4,4 \\
$4-153$ & 7,3 & 6,6 & 7,3 & 6,6 & 6,6 & 34,3 & 6,9 \\
$4-163$ & 9,2 & 8,3 & 7,4 & 6,8 & 7,8 & 39,7 & 7,9 \\
Среднее & 7,1 & 5,9 & 6,6 & 5,9 & 6,3 & 31,8 & 6,4 \\
значение & & & & & & & \\
\hline
\end{tabular}

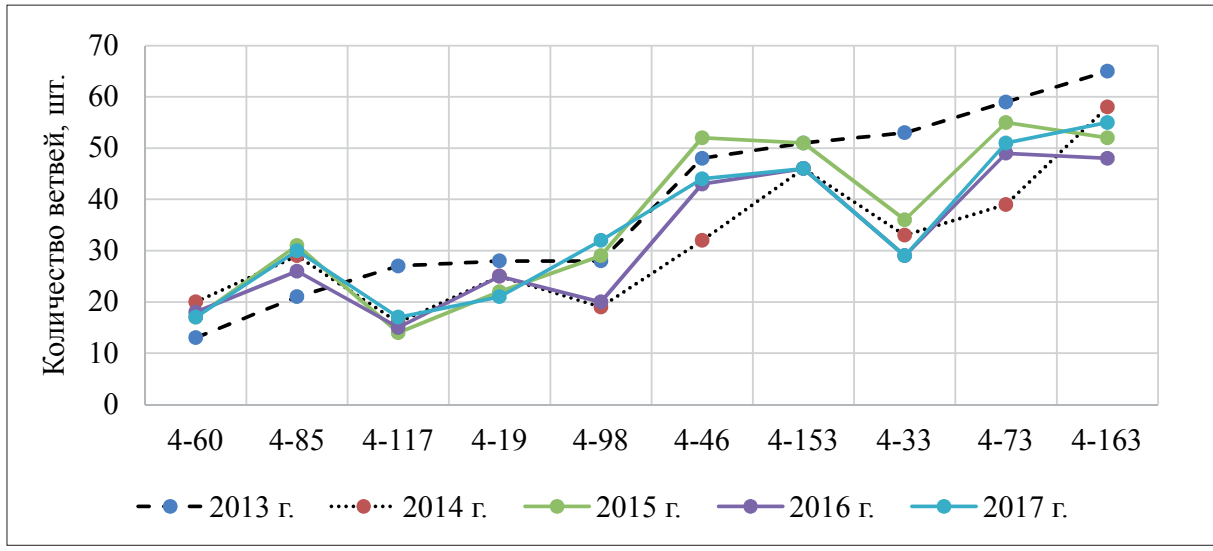

Рис. 3. Количество боковых ветвей в мутовках за 5-летний период 


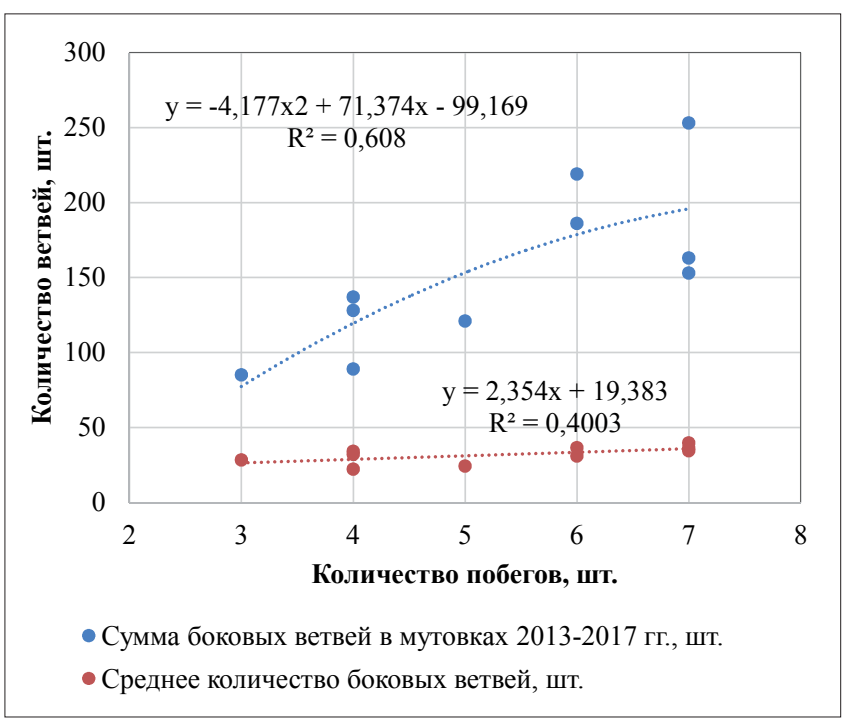

Рис. 4. Зависимость между количеством лидирующих побегов и боковых ветвей в мутовках в период 2013-2017 гг.

Выводы. При декапитации деревьев Pinus sibirica необходимо учитывать показатели их роста и развития, отдавая предпочтение экземплярам, имеющим наибольшее количество хорошо развитых боковых ветвей в нижних мутовках, диаметр ствола большего размера. При обрезке деревьев кедра сибирского 42-летнего возраста на высоте 1,4-1,7 м при диаметре ствола 9,5-22,5 см через 12 лет сформировались 3-7 лидирующих побегов при 4,4-7,9 шт. боковых ветвей в мутовках. Установлена тесная связь между диаметром ствола и числом лидирующих побегов, числом лидирующих побегов и количеством сформированных боковых ветвей спустя 7-12 лет после декапитации, диаметром ствола при обрезке верхней части кроны и высотой деревьев после 12 лет декапитации.

\section{Список літератури}

Белобородов В.М. (1979). Цели и возможности обрезки деревьев сосны на семенных плантациях. Селекичионые основы повыиения продуктивности лесов, 1, 59-64. [Beloborodov, V. M. (1979). Goals and the possibility of pruning pine trees on seed plantations. Selection bases for increasing forest productivity, 1, 59-64] (in Russian)

Бех И.А. (1989). Поломка и смена вершин у молодых деревьев кедра сибирского. Проблемы кедра. Организачия комплексного хозяйства, 6369 [Beh, I.A. (1989). Breakdown and change of peaks in young siberian cedar trees. In Cedar problems. Organization of complex economy, 63-69] (in Russian)

Братилова Н.П. (2015). Влияние декапитации крон на биологическую продуктивность сосны кедровой сибирской. Хвойные бореальной зоны, 33(3-4), 113-115. [Bratilova, N.P. (2015). Effect of crown decapitation on biological productivity of cedar Siberian pine. Conifers of the boreal area, 33(3-4), 113-115. Retrieved from https://cyberleninka.ru/article/n/vliyanie- dekapitatsii-kron-na-biologicheskuyu-produktivnost-sosny-kedrovoy-sibirskoy/viewer] (in Russian)

Братилова Н.П., Шамова С. С. (2014). Отбор деревьев кедровых сосен с повышенной восстановительной способностью после декапитации. Хвойные бореальной зоны, 32(3-4), 15-19. [Bratilova, N.P., \& Shamova, S.S. (2014). Selection of siberian cedar trees with increased restorative capacity after decapitation. Conifers of the boreal area Xвойнble бореальной зоны, 32(3-4), 15-19. Retrieved from https:// cyberleninka.ru/article/n/otbor-dereviev-kedrovyh-sosens-povyshennoy-vosstanovitelnoy-sposobnostyu-posledekapitatsii/viewer] (in Russian)

Вересин М.М., Ефимов Ю.П., Арефьев Ю.Ф. (1985). Справочник по лесному селекционному семеноводству. Москва: Агропромиздат. 245 с. [Veresin, M. M., Efimov, Yu. P., \& Arefiev, Yu. F. (1985). Forest seed breeding guide. Moskow: Agropromizdat] (in Russian)

Водин А. В., Шкикунов В.Г., Селюк П.П. (2002). Особенности репродуктивной деятельности кедра сибирского путем обрезки верхней части кроны. Плодоводство, семеноводство, интродукция древесных растений: материалы $\mathrm{V}$ международ. науч. конф. (Красноярск, 15-17 сентября 2002 г.). Красноярск: СибГТУ, 2002. C. 9-11. [Vodin, A. V., Shikkunov, V.G., \& Seluk, P.P. (1999). Features of siberian cedar reproductive activity by trimming the top of the crown. In Gardening, seed growing, introduction of woody plants (pp. 9-11). Krasnoyarsk: SibSTU] (in Russian)

Долголиков, В.И. (1981). Создание низкорослых семенных плантаций сосны обыкновенной: практические рекомендации. Ленинград: ЛитНИИЛХ. 18 с. [Dolgolicov, V.I. (1981). Creation of low-grown pine ordinary plantations: practical recommendations. Leningrad: LitNIILH] (in Russian)

Извекова И.М. (1972). Влияние обрезки кроны на рост сосны и ели. Лесной журнал, 4, 7-10 [Isvekova, I.M. (1972). Effect of pruning the crown on the growth of pine and spruce. Forestry Journal, 4, 7-10] (in Russian)

Мамаев С.А. (1973). Формыл внутривидовой изменчивости древесных растений. Москва: Наука. 284 с. [Mamaev, S.A. (1973). Forms of intraspecific variability of woody plants. Moskow: Science] (in Russian)

Матвеева Р.Н., Буторова О.Ф., Нарзяев В.В., Гришлов Д.А., Иванов В.С. (2018). Показатели 50-летней сосны кедровой сибирской после декапитации кроны на плантации «ЛЭП-1» (пригородная зона Красноярска). Хвойные бореальной зоньл, 36(6), 502-506. [Matveeva, R. N., Butorova, O.F., Narziyaev, V.V., Grishlov, D.A., \& Ivanov, V.S. (2018). 50-year-old cedar Siberian pine after the decapitation of the crown on the «LEP-1» plantation (Krasnoyarsk suburban area). Conifers of the boreal area, 36(6), 502-506. Retrieved from https://cyberleninka.ru/ article/n/pokazateli-50-letney-sosny-kedrovoy-sibirskoy- 
posle-dekapitatsii-krony-na-plantatsii-lep-1-prigorodnaya-zona-goroda-krasnoyarska] (in Russian)

Никитенко Е.А. (2010). Многовершинность кедра корейского на лесосеменных плантациях. Лесоведение, 1, 46-52. [Nikitenko, E.A. (2010). The majority of Korean cedar on forest plantations. Forest science, 1, 46-52. http://lesovedenie.ru/index.php/forestry/ article/view/342] (in Russian)

Попов А. С. (1982). Влияние обрезки на рост сосны. Лесоведение, 3, 72-75 [Popov, А.S. (1982). Effect of pruning on pine growth. Forest science, 3, 72-75] (in Russian)

Родин А. Р., Тимофеев В. В. (1989). Влияние обрезки центрального побега лиственницы Сукачева на ее семеношение. Науч. труды МЛТИ: Современные методы вырашцивания древесных насаждений на селекционно-генетической основе, 221, 26-28. [Rodin, A. R., \& Timofeyev, V. V. (1989). Influence of the central shoot pruning of Sukachev larch on its seed production. Scientific works of the Moscow Forestry Institute: Modern methods of growing tree stands on a selection and genetic basis, 221, 26-28] (in Russian)

Тараканов В.В., Демиденко В.П., Ишутин Я.Н., Бушков Н. Т. (2001). Селекционное семеноводство сосны обыкновенной в Сибири. Новосибирск: Наука, 230 с. [Tarakanov, V.V., Demidenko, V.P., Ishutin, J. N., \& Bushkov, N.T. (2001). Selective seed production of scots pine in Siberia. Novosibirsk: Science] (in Russian)

Щерба Н.П., Водин А.В. (2000). Влияние качества посадочного материала, агротехники выращивания и декапитации крон на рост и формирование фитомассы кедра сибирского. Красноярск: СибГТУ. 84 с. [Scherba, N.P., \& Vodin, A. V. (2000). Influence of the quality of planting material, agrotechnics of cultivation and decapitation of crowns on the growth and formation of Siberian cedar phytomass. Krasnoyarsk: Siberian State Technical University] (in Russian)

Bae C.-H., Song J.-M., Kim C.-W., Song J.-H., Han S.-U., Shim T.-H., \& Yi J.-S. (2008). Comparison of seed component between stempruned and un-pruned trees in a Pinus koraiensis seed. Annals Forest Research, 51, 157-158. Retrieved from www. afrjournal.org

Fernandez, M.P., Basauri, J., Madariaga, C., Menéndez-Miguélez, M., Olea, R., \& Zubizarreta-Gerendiain, A. (2017). Effects of thinning and pruning on stem and crown characteristics of radiata pine (Pinus radiata D. Don). Biogeosciences and Forestry, 10, 383-390. https://doi.org/10.3832/ifor2037-009.

Jae-Seon, Y., Chul-Woo Kim, Hyun-Seok Lee, \& Chan-Hoon An. (2009). Crown control for sustainable management of Pinus koraiensis S. et Z. plantation. In The state of the Far East forests and current problems of forest management. Khabarovsk, Russia: DalNIILH (pp. 296-298)

Mäkinen, H., Verkasalo, E., \& Tuimala, A. (2014). Effects of pruning in Norway spruce on tree growth and grading of sawn boards in Finland. Forestry:
International Journal of Forest Research, 87(3), 417424. https://doi.org/10.1093/forestry/cpt062

Mederski, P. S., Bembenek M., \& Nadolna D. (2013). Impact of pruning on the increment of scots pine (Pinus sylvestris L.) from a seedling seed orchard. Forest letters, 105, 28-34. Retrieved from https:// www.researchgate.net/figure/Wood-properties-comparison-of-Scots-pine-Pinus-sylvestris-L-from-SSOand-regular_tbl2_292156628

Moreno-Fernández, D., Sánchez-González, M., González, J. G., Hevia, A, Majada, J.P., Cañellas, I., \& GeaIzquierdo, G. (2014). Response to the interaction of thinning and pruning of pine species in Mediterranean mountaeins. European Journal Forest Research, 133(5), 833-843. https://doi.org/10.1007/ s10342-014-0800-z

\section{Formation of crown for Siberian cedar over a 12-year period after decapitation (suburban area of Krasnoyarsk)}

\author{
D. Grishlov', N. Bratilova², R. Matveeva ${ }^{3}$, \\ O. Butorova ${ }^{4}$
}

Trees are decapitated to form a low-topped crown to improve cuttings and cone harvesting conditions. To do this, offer different methods of crowns decapitation with an intensity of $55-75 \%$. The stimulating effect of pruning on the productivity of trees, the crowns growth, and the formation of multi-tops estimated. The plantations of Siberian cedar Pinus sibirica Du Tour are established to obtain valuable seeds and improve the environmental conditions in the suburban area of large industrial centers of Siberia. The Siberian cedar is distinguished not only by its high silvicultural characteristics, but also by the nutritional quality of its pine "nuts". The aim of the research was to establish the peculiarities of crown formation for Siberian cedar on the

Dmitriy Grishlov - postgraduate student of the Department of breeding and planting. Reshetnev Siberian State University of Science and Technology, Krasnoyarsk, Russian Federation. Tel.: (391)222-73-95. E-mail: grishlova@mail.ru ORCID: https:// orcid.org/0000-0003-3734-2541

Natalia Bratilova - Doctor of Agricultural Sciences, head of the Department of breeding and planting. Reshetnev Siberian State University of Science and Technology, Krasnoyarsk, Russian Federation. Tel.: (391)222-73-95. E-mail: nbratilova@yandex.ru ORCID: https://orcid.org/0000-0002-2918-9690

Rimma Matveeva - Doctor of Agricultural Sciences, Professor of the Department of breeding and planting. Reshetnev Siberian State University of Science and Technology, Krasnoyarsk, Russian Federation. Tel.: (391)227-58-09. E-mail: matveevarn@yandex.ru ORCID: https://orcid.org/0000-0002-3476-9622

Olga Butorova - Doctor of Agricultural Sciences, Professor of the Department of breeding and planting. Reshetnev Siberian State University of Science and Technology, Krasnoyarsk, Russian Federation. Tel.: (391)227-58-09. E-mail: Butorova.olga@mail.ru ORCID: https://orcid.org/0000-0001-8575-7464 
plantation "Meteostation" over a 12-year period after decapitation. The plantation was established under the supervision of R. N. Matveeva. Planting scheme $5 \times 5$ $\mathrm{m}$ applied. The object of the research was 54-year-old Siberian cedar grown from seeds harvested in 1964 in Leninogorsk Forestry of the Republic of Kazakhstan. The decapitation was performed for trees of 42 years old in 2005 at the height of 1.4-1.7 m. The height of the trees before decapitation varied from 3.3 to $4.5 \mathrm{~m}$, the trunk diameter - from 9.5 to $23.6 \mathrm{~cm}$. The average crown diameter was $3.8-4.3 \mathrm{~m}$. The upper part of the crown is removed by $50.0-66.7 \%$. The trees were measured for height, growth of the leading shoots replacing the central shoot, and trunk diameter at the soil surface. The level of variability was assessed according to S. A. Mamaev scale.

By 2017, the trees had reached the height of 5.6$9.1 \mathrm{~m}$; the number of leading shoots replacing the central one was 3-7. Trees with a trunk diameter of $12-18 \mathrm{~cm}$ had 3-4 leading shoots replacing the central one; those with a diameter of $20-26 \mathrm{~cm}$ had 6-7 shoots each. Linear growth of branches replacing the central shoot for the 12-year period was 4.0-7.6 m. The maximum growth was noted in tree 4-98: 7.0-90.0 \% more than the others. Trees 4-33, 4-46, 4-73, 4-117 had the largest trunk diameter. It was found that the level of variability of tree height is low; growth, trunk diameter - medium, the number of leading shoots high. The highest height $(9.1 \mathrm{~m})$ had the tree number $4-98$, exceeding the others by $8.3-62.5 \%$. The average number of lateral branches formed during the 5-year period on the leading shoots was compared. Between 2013 and 2017, the average growth was between 23.6 and $45.5 \mathrm{~cm}$. The highest value of average growth over the 5-year period $(45.5 \mathrm{~cm})$ was in tree number $4-73$, which was $12.1-71.0 \%$ higher than the others. Trees 4-117 and 4-33 were distinguished by weak growth, where the average growth was $23.6-29.9 \mathrm{~cm}$.

The average number of lateral branches formed during the 5-year period on the leading shoots was compared: by $4.4-7.9$ branches of 3.6 to $2.0 \mathrm{~m}$ in length. The greatest length of lateral branches was on tree No. 4-85. Weak branch formation in whorls was observed in tree 4-117. A close direct correlation was established between the diameter of the trunk and the number of leading shoots; the number of leading shoots and the total number of lateral branches on the shoots; the trunk diameter during pruning, and the height of trees after 12 years of decapitation. The decapitation has resulted in the formation of a multitrunk crown in Siberian cedar trees. When decapitating Siberian cedar trees, it is necessary to give preference to the specimens that have the largest number of developed lateral branches in the lower whorls, the trunk diameter is larger. It is recommended to leave at least 6-7 leading shoots during decapitation.

Key words: Siberian cedar; growth; plantation; leading shoot; pruning the crown; Leninogorsk origin; Krasnoyarsk region.

\section{Формування крони кедра сибірського за 12-річний період після декапитації (приміська зона м. Красноярська)}

\author{
Д.А. Гришлов ${ }^{1}$, Н. П. Братілова ${ }^{2}$, \\ Р.Н. Матвєєва ${ }^{3}$, О.Ф. Буторова ${ }^{4}$
}

Декапітацію дерев здійснюють 3 метою формування низькоопущеної крони для поліпшення умов нарізання живців і збору шишок. Для цього пропонують різні способи декапітації крон 3 інтенсивністю 55-75\%. Відзначено стимулюючий вплив обрізки на ріст самих дерев, розростання крон, формування багатовершинності. Плантації Pinus sibirica Du Tour створюють для отримання цінного насіння і поліпшення умов довкілля в приміській зоні великих промислових центрів Сибіру. Мета досліджень полягала у встановленні особливостей формування крони кедра сибірського на плантації «Метеостанція» впродовж 12-річного періоду після декапітації. Плантація створена за схемою садіння $5 \times 5$ м. Об'єктом досліджень було 54-річне насадження Pinus sibirica, вирощеного із насіння, заготовленого в 1964 р. у Леніногорському лісгоспі Республіки Казахстан. Декапітація була проведена у дерев 42-річного віку в 2005 р. на висоті 1,4-1,7 м. Висота дерев до декапітації змінювалась від 3,3 до 4,5 м, діаметр стовбура - від 9,5 до 23,6 см. Середній діаметр крони становив 3,8-4,3 м. Частка видалення верхньої частини крони становила 50,0-66,7\%. У дерев вимірювали висоту, приріст за висотою лідируючих пагонів, які замінили центральний, діаметр стовбура біля поверхні грунту.

До 2017 р. дерева досягли висоти 5,6-9,1 м. Кількість лідируючих пагонів, які замінили централь-

Гришлов Дмитро Андрійович - аспірант кафедри селекції та озеленення. Сибірський державний університет науки $\mathrm{i}$ технологій імені академіка М.Ф. Решетньова, пр. Миру, 82, м. Красноярськ, 660049, Росія. Тел.: (391)222-73-95. E-mail: grishlova@mail.ru ORCID: https://orcid.org/0000-0003-37342541

Братілова Наталя Петрівна - доктор сільськогосподарських наук, завідувач кафедри селекції та озеленення. Сибірський державний університет науки i технологій імені академіка М. Ф. Решетньова, пр. Миру, 82, м. Красноярськ, 660049, Росія. Тел.: (391)222-73-95. E-mail: nbratilova@yandex.ru ORCID: https://orcid.org/0000-0002-2918-9690

Матвєєва Рімиа Нікітічна - доктор сільськогосподарських наук, професор кафедри селекції та озеленення. Сибірський державний університет науки і технологій імені академіка М.Ф. Решетньова, пр. Миру, 82, м. Красноярськ, 660049, Росія. Тел.: (391)227-58-09. E-mail: matweevarn@yandex.ru ORCID: https://orcid.org/0000-0002-3476-9622

Буторова Ольга Федорівна - доктор сільськогосподарських наук, професор кафедри селекції та озеленення. Сибірський державний університет науки і технологій імені академіка М.Ф. Решетньова, пр. Миру, 82, м. Красноярськ, 660049, Росія. Тел.: (391)227-58-09. E-mail: Butorova.olga@mail.ru ORCID: https://orcid.org/0000-0001-8575-7464 
ний, склала 3-7 шт. Дерева 3 діаметром стовбура 12-18 см мали по 3-4 лідируючих пагонів, 3 діаметром 20-26 см - по 6-7 шт. Лінійний приріст гілок, які замінили центральний пагін, за 12-річний період склав 4,0-7,6 м. Максимальний приріст відзначений у дерева 4-98, який на 7,0-90,0\% більший порівняно з іншими особинами. Найбільшим діаметром стовбура характеризувалися дерева № 4-33, 4-46, 4-73, 4-117.

Встановлено, що рівень мінливості висоти дерев низький, приросту за висотою, діаметром стовбура - середній, кількості лідируючих пагонів - високий. Найбільшою висотою $(9,1$ м) вирізнялося дерево № 4-98, перевершуючи за цим показником інші особини на 8,3-62,5\%. За період з 2013 по 2017 pp. середній висотний приріст знаходився в межах 23,6-45,5 см. Найбільше значення середнього приросту за 5-річний період (45,5 см) встановлено у дерева № 4-73, що на 12,1-71,0\% більше порівняно з іншими особинами. Слабким висотним приростом характеризуються дерева 4-117 та 4-33, де значення середнього приросту склало 23,6-29,9 см. Середня кількість бічних гілок, що утворилися за 5-річний період на лідируючих пагонах, становила 4,4-7,9 шт. завдовжки 2,0-3,6 м. Найбільша довжина бічних гілок встановлена у дерева № 4-85. Слабке формування гілок у мутовках спостережено у дерева 4-117. Встановлено тісний прямий зв'язок між кількістю лідируючих пагонів і сумарною кількістю бічних гілок на пагонах, діаметром стовбура і висотою дерев через 12 років після декапітації. Внаслідок декапітаціі у дерев кедра сибірського сформувалася багатовершинна крона. Під час декапітації дерев кедра сибірського необхідно віддавати перевагу екземплярам, які мають найбільшу кількість розвинених бічних гілок у нижніх мутовках і діаметр стовбура більшого розміру. Рекомендовано в процесі декапітації залишати не менше 6-7 лідируючих пагонів.

Ключові слова: кедр сибірський; приріст; плантація; лідируючий пагін; леніногорське походження; Красноярський край. 